\title{
Islam Kaffah Menurut Pandangan Ibnu Katsir
}

\author{
Riana Ratna Sari \\ Fakultas Ushuluddin, Adab dan Dakwah IAIN Kerinci \\ ratnasaririana27@gmail.com
}

\begin{abstract}
Islam can play a role in buman life from all aspects of the problems faced by humans, both human crisis problems because Islam provides all that is needed by bumans if it is understood, lived and practiced as a whole, which in its religious language is Islam kaffah (overall) So that from there born a noble attitude and character. To understand the meaning of Islam in a kaffah (overall) way, the researcher takes Ibn Kathir's interpretation and understanding of Islam in Ibn Kathir's Tafsir. The reasons for raising the figure of Ibn Kathir include, first, that he is one of the most influential contemporary scholars in Indonesia so that it will be easier to understand the contextualization between Islam and the environment and the Indonesian Muslim community. Second, Ibn Kathir's thoughts in the field of interpretation are widely known and followed by the Indonesian people because in interpreting the Qur'an he uses simple, light, and easy to understand language by both academics and the general public. The purpose of this research is to find out the Kaffah Islamic verses in the al-Qur'an; To find out how Islam Kaffah is in Ibn Kathir's interpretation; To find out the contribution of Ibn Kathir's interpretation of Islam.
\end{abstract}

\section{Keyword : Islam Kaffah, Ibnu Katsir}

Abstrak. Islam dapat berperan dalam kehidupan manusia dari segala aspek permasalahan yang dihadapi oleh manusia, baik permasalahan krisis manusia itu sendiri karena Islam memberikan semua yang dibutuhkan oleh manusia jika dipahami, dihayati, dan diamalkan secara menyeluruh, yang dalam bahasa agamanya yaitu Islam kaffah (menyelurub), sehingga dari sana lahirlah sikap dan akhlak yang mulia. Untuk memahami makna Islam secara kaffah (menyeluruh), peneliti mengambil penafsiran dan pemahaman Ibnu Katsir terkait dengan Islam dalam Tafsir Ibnu Katsir. Adapun alasan-alasan mengangkat tokoh Ibnu Katsir antara lain, pertama, ia merupakan salah satu ulama kontemporer yang sangat berpengaruh di Indonesia sehingga akan lebih mudah untuk memahami kontekstualisasi antara Islam dengan lingkungan dengan masyarakat muslim Indonesia. Kedua, pemikiran Ibnu Katsir di bidang tafsir banyak dikenal dan diikuti oleh masyarakat Indonesia karena dalam menafsirkan al-Qur'an ia menggunakan bahasa yang sederhana, ringan, dan mudah dimengerti baik oleh kalangan akademisi maupun masyarakat umum. Tujuan penelitian ini untuk mengetahui ayat-ayat Islam Kaffah dalam al-Qur'an; Untuk mengetahui bagaimanakah Islam Kaffah dalam tafsir Ibnu Katsir; Untuk mengetahui kontribusi penafsiran Ibnu Katsir terhadap Islam.

\section{Kata Kunci : Islam Kaffah, Ibnu Katsir}




\section{PENDAHULUAN}

Islam dapat berperan dalam kehidupan manusia dari segala aspek permasalahan yang dihadapi oleh manusia, baik permasalahan krisis manusia itu sendiri karena Islam memberikan semua yang dibutuhkan oleh manusia jika dipahami, dihayati, dan diamalkan secara menyeluruh, yang dalam bahasa agamanya yaitu Islam kaffah (menyeluruh), sehingga dari sana lahirlah sikap dan akhlak yang mulia.

Kata kaffah di dalam al-Qur'an terdapat satu kali yaitu dalam Q.S. alBaqarah ayat 208, dan Islam secara menyeluruh di dalam al-Qur'an terdapat dalam surat al-Baqarah ayat 208, surat an-Nisa' ayat 125, surat al-An'am ayat 153 dan 162 (Sukmadjaja \& Yusuf, 2000, h. 82). Untuk memahami makna Islam secara kaffah (menyeluruh), peneliti mengambil penafsiran dan pemahaman Ibnu Katsir terkait dengan Islam dalam Tafsir Ibnu Katsir. Adapun alasan-alasan mengangkat tokoh Ibnu Katsir antara lain, pertama, ia merupakan salah satu ulama kontemporer yang sangat berpengaruh di Indonesia sehingga akan lebih mudah untuk memahami kontekstualisasi antara Islam dengan lingkungan dengan masyarakat muslim Indonesia. Kedua, pemikiran Ibnu Katsir di bidang tafsir banyak dikenal dan diikuti oleh masyarakat Indonesia karena dalam menafsirkan al-Qur'an ia menggunakan bahasa yang sederhana, ringan, dan mudah dimengerti baik oleh kalangan akademisi maupun masyarakat umum.

Upaya memahami corak penafsiran Ibnu Katsir dalam Tafsir Ibnu Katsir terutama yang berkaitan dengan kata Islam menjadi motivasi sekaligus urgensi dalam penelitian ini untuk mengungkap Islam kaffah (menyeluruh) menurut Ibnu Katsir serta kontribusinya dalam khazanah Tafsir al-Qur'an.

Tujuan penelitian ini untuk mengetahui ayat-ayat Islam Kaffah dalam al-Qur'an; Untuk mengetahui bagaimanakah Islam Kaffah dalam tafsir Ibnu Katsir; Untuk mengetahui kontribusi penafsiran Ibnu Katsir terhadap Islam. 
Pembahasan tentang Islam bukanlah sesuatu yang baru. Dalam beberapa kajian, uraian mengenai Islam sering diangkat ke permukaan, terutama berbicara mengenai konsep Islam. Karya yang cukup spesifik dan komprehensif yang membahas persoalan ini adalah buku yang berjudul Studi Islam Komprehensif karangan Abuddin Nata (Sukmadjaja \& Yusuf, 2000, h. 82). Dalam buku ini dijelaskan bahwasanya Islam tidak hanya mencakup hubungan manusia dengan Tuhannya atau manusia dengan manusia karena Islam jauh lebih luas dari pada kedua hal itu. Di dalamnya terdapat ulasan yang cukup komprehensif seperti sumber ajaran, prinsip, tujuan dan sasaran, karakteristik dan ruang kerja Islam yang dipaparkan secara sistematis.

Adapun buku yang berjudul Islam dalam Berbagai Dimensi yang ditulis oleh Daud Rasyid menjelaskan ruang-ruang yang ada di dalam agama Islam, di dalamnya dikatakan bahwa Islam adalah agama yang universal. Dengan demikian pemahaman terhadap Islam tergantung dari sudut mana seseorang memandangnya. Ketika seseorang memandang Islam dari optic social maka pemahamannya menjadi sosial. Ketika memandang Islam dari sudut pandang hukum, maka Islam menjadi tatanan hukum dan begitu seterusnya. Namun demikian, buku ini tidak menerangkan konsep Islam secara utuh (Rasyid, 1998).

Satu lagi penelitian yang menempatkan M. Quraish Shihab sebagai objek kajian adalah skripsi yang berjudul Konsep Islam Menurut Pandangan M. Quraish Shihab dalam Tafsir al-Misbah. Skripsi ini mengemukakan secara utuh, sistematis, dan mendalam dengan memaparkan derivasi dan variasi makna kata Islam dalam al-Qur'an menurut penafsiran Quraish Shihab (Mohari, 2015).

Sampai di sini, penulis dapat mengambil standing point untuk membahas Islam kaffah menurut pandangan Ibnu Katsir kajian tafsir Ibnu Katsir sebagai penelitian yang berbeda dan orisinil. Penelitian ini akan menjelaskan Islam kaffah secara utuh dan sistematis menurut pandangan Ibnu 
Katsir. Di samping itu, penulis juga menerangkan kontribusi-kontribusi penafsiran Ibnu Katsir dalam Islam yang utuh dan ideal. Hal inilah yang membedakan penelitian sebelumnya dengan penelitian ini.

Penelitian ini merupakan library research (penelitian kepustakaan). Di mana sumber-sumber yang dijadikan data berasal dari perpustakaan, seperti kitab, buku-buku, majalah, jurnal, artikel dan lain-lain. Penulis menggunakan jenis penelitian analisis deskriptif, yaitu semua isyarat yang berhubungan dengan pokok bahasan dideskripsikan.

Penelitian ini juga menggunakan metode tafsir maudhu'i, metode ini membahas tentang masalah-masalah al-Qur'an al-Karim yang (memiliki) kesatuan makna atau tujuan dengan cara menghimpun ayat-ayatnya yang bisa juga disebut metode taubidi (kesatuan) untuk kemudian melakukan penalaran (analisis) terhadap isi kandungannya menurut cara-cara tertentu, dan berdasarkan syarat-syarat tertentu untuk menjelaskan makna-maknanya dan mengeluarkan unsur-unsurnya, serta menghubung-hubungkan antara yang satu dan lainnya dengan kolerasi yang bersifat komprehensif (Izzan, 2007, h. 115).

\section{HASIL DAN PEMBAHASAN}

\section{Biografi Ibnu Katsir}

Ibnu Katsir yang nama aslinya adalah Imaduddin Isma’il bin Umar bin Katsir al-Bashri, al-Dimisqi, al-Faqih, al-Syafi'i. Ibnu Katsir lahir pada tahun 701 di Timur Bashri yang merupakan wilayah bagian Damaskus. Ketika berusia dini, Ibnu Katsir sudah memulai kembara ilmiahnya. Di usia tujuh tahun ia mengunjungi Damaskus bersama saudaranya pada tahun 706 (Mahmud, 2006, h. 64).

Nama lengkap Ibnu Katsir adalah Abu Fida Imaduddin Isma'il bin Umar bin Katsir Al Qurasyi Al Bushrawi Ad Dimasyqi. Disebut As Bushrawi karena dia lahir di Bushra, sedangkan disebut Ad Dimasyqi karena beliau tumbuh, berkembang, dan belajar di Damaskus. 
Beliau dilahirkan di desa yang bernama Majdal di pinggiran kota Bushra pada $701 \mathrm{H}$. ayahnya merupakan seorang khatib (kiai) di desanya. Beliau baru berumur empat tahun ketika ditinggal ayahnya yang menemui sang pencipta. Sejak kematian sang ayah, beliau diasuh oleh pamannya, Syekh Abdul Wahhab, yang mengajarkannya ilmu-ilmu dari dasar. Tidak berapa lama kenudian, tepatnya tahun $706 \mathrm{H}$, saat umurnya baru menginjak lima tahun, beliau pindah ke Damaskus, Syam (sekarang Suriah).

Ibnu Hajar Al-Asqalani menyebutkan bahwa pada akhir hayatnya, Ibnu Katsir mengalami gangguan mata (buta) dan wafat di Damaskus, Suriah, pada $774 \mathrm{H}$. mudah-mudahan Allah menempatkannya di surga-Nya yang lapang (Mubarakfury, 2012, h. viii-xii)

Dalam kitabnya yang berjudul Al Mujam Al Mukbtashsh, Adz Dzahabi berkata, "Ibnu Katsir merupakan seorang imam, mufti (pemberi fatwa), ahli hadis yang jenius, ahli fikih, ahli tafsir, dan memiliki banyak sekali karya tulis yang sangat bermanfaat bagi umat Islam."

Dalam kitabnya yang berjudul Ad Durarul Kaminah, Ibnu Hajar Al Asqalani berkata, "Ibnu Katsir selalu menyibukkan dirinya dengan menelusuri hadits-hadits, baik dari segi teks isi maupun para perawinya. Beliau rajin meringkas berbagai bidang ilmu untuk memberikan kemudahan bagi khalayak umum. Beliau juga ramah terhadap semua orang. Selama hidup, beliau telah menulis banyak buku yang bermanfaat bagi kaum muslimin pada masa-masa berikutnya."

Abu Mahasin Jamaluddin Yusuf bin Saifuddin, seorang ahli sejarah yang terkenal dengan sebutan Tgri Bardi, dalam kitabnya yang berjudul $A l$ Manbal Ash Shafi wal Mustanfi Ba'dal Wafi, berkata tentang Ibnu Katsir, "Beliau adalah seorang syekh yang sangat dalam ilmunya; patut dijadikan sandaran bagi agama Islam; orang yang suka berkorban (abul fida); selalu menyibukkan diri dengan ilmu; selalu berkarya; sangat dalam memahami fikih, tafsir, dan hadits; senang megoleksi buku-buku dan meringkas atau 
menyusunnya kembali; senang mengajar; memiliki perhatian tinggi terhadap hadits, tafsir, fikih, dan bahasa Arab; serta rajin memberikan fatwa dan menyebarkannya kepada umat Islam sampai beliau wafat. Selain itu, beliau terkenal dengan sifatnya yang berhati-hati dalam menyebarkan ilmunya. Sampai wafatnya, beliau sering disebut sebagai ulama terdepan dalam bidang sejarah, hadist, dan tafsir (Mubarakfury, 2012, h. ix-x).

Dalam bidang fikih, beliau berguru kepada Syekh Burhanuddin Ibrahim bin Abdurrahman Al Fazari yang terkenal dengan sebutan Ibnu Farkah (wafat tahun 729 H). Dalam bidang bacaan al-Qur'an, di Damaskus beliau berguru kepada ulama-ulama sebagai berikut: Isa bin Muth'im, Ahmad bin Abu Thalib yang terkenal dengan sebutan Ibnu Syahnah, (wafat tahun 730 H), Ibnu Hijar (wafat tahun 730 H), Musnadisy Syam Bahanuddin Qasim bin Muzhaffar bin Asakir (wafat tahun 733 H), Ibnu Syairazi, Ishaq bin Yahya Al Amadi Syekh Az Zhahiriyah Afifuddin (wafat tahun $725 \mathrm{H}$ ), Muhammad bin Zarrad, Lazimusy Syekh Jamaluddin Yusuf bin Zakki Al Mizzi (wafat tahun $742 \mathrm{H}$ ) bahkan, dia dinikahkan dengan salah seorang putrid gurunya ini, Syekhul Islam Taqiyyuddin Ahmad bin Abdul Halim bi Abdussalam bin Taimiyyah (wafat tahun $728 \mathrm{H}$ ), Syekh Syamsuddin Muhammad bin Ahmad bin Utsman bin Qaimaz Adz Dzahabi (wafat tahun $748 \mathrm{H}$ ), seorang ahli sejarah. Adapun di Mesir, beliau berguru kepada ulamaulama sebagai berikut: Abu Musa Al Qurafi, Abu Fath Ad Dabusi, Ali bin Umar As Sawani.

Murid-murid Ibnu katsir sangat banyak, salah satunya adalah Ibnu Hujji. Ibnu Hujji berkata tentang Ibnu Katsir, "Bagi kami, orang yang paling hafal teks-teks hadits adalah Ibnu Katsir. Beliau juga sangat menguasai riwayat para perawi dan perbedaan antara hadits yang sahih dan hadits yang daif. Semua sahabat dan gurunya pun mengakui hal itu. Saat aku bersamanya, tidak pernah terlewat sedetik pun beliau memberikan manfaat dan hikmah untukku." 
Ibnu Imad Al Hanbali dalam kitabnya yang berjudul Syadæratudz, Drabab fi Akbbarin min Dzahab mengatakan, "Ibnu katsir adalah seorang hafiz besar, patut dijadikan sandaran bagi agama Islam, banyak merangkum bukubuku, jarang lupa, hafalannya kuat, dan ahli bahasa Arab.”

Ibnu Habib mengatakan, "Ibnu Katsir orang yang jeli saat mendengar ilmu, senang mengoleksi ilmu, menulis banyak karya, sering mengeluarkan fatwa dalam mencari solusi permasalahan umat, suka menegur, dan karyakaryanya tersebar keseluruh penjuru dunia. Beliau juga terkenal dengan sifatnya yang berhati-hati dalam menyebarkan ilmunya."

Karya-karya Ibnu Katsir sangat banyak, di antaranya: (a) Tafsirul Qur'anil Karim: kitab ini merupakan karyanya yang paling fenomenal dan disebut-sebut sebagai kitab tafsir (yang ditulis dengan metode riwayah) paling lengkap. Kitab ini telah dicetak berkali-kali dan diteliti oleh banyak ulama/ilmuwan. (b) Al Bidayah wan Nihayah: kitab yang terdiri dari empat belas jilid ini membicarakan kisah para nabi dan umat terdahulu, sirah Nabi Muhammad saw., serta sejarah umat Islam. Selain itu, Ibnu Katsir mengetengahkan tema yang disebut sebagai "fitnah-fitnah dan latar belakang terjadinya hari kiamat serta hal-hal yang berkaitan dengan akhirat". Kalimat terakhir itulah yang disebut sebagai An Nibayah. Dalam proses percetakannya, awalnya hanya $A l$ Bidayah yang dicetak, baru kemudian menyusul $A n$ Nihayah. Kitab ini telah di-tahqiq oleh banyak ulama. (c) At Takmil fi Ma'rifatits Tsiqat wadh Dhu'afa wal Majabil: isi kitab ini merupakan gabungan dua kitab karya dua guru Ibnu Katsir, yaitu Al Mizzi (Tahdzibul Kamal fi Asmair Rijal) dan Adz Dzahabi (Mizanul I'tidal fi Naqdir Rijal). Namun, Ibnu Katsir telah membumbuinya dengan beberapa tambahan yang disesuaikan kemampuannya dalam menguasai ilmu al jarh wal i'tidal (menilai validitas para perawi). (d) Al Hadyu was Sunan fi Ahaditsil Masanid was Sunan: kitab ini lebih dikenal dengan nama Jami'ul Masanid. Kitab ini menggabungkan antara musnad-musnad karya Ahmad bin Hanbal, Al Bazar, Abu Ya’la Al Mushili, 
dan Ibnu Abi Syaibah serta Al Kutubut Tis'ah (enamkitab hadits karya Al Bukhari, Muslim, At Tirmidzi, An Nasa'I, Abu Dawud, dan Ibnu Majah). (e) Thabaqatusy Syafi'iyyah: kitab ini dicetak dalam bentuk satu jilid agak besar. Di dalamnya terdapat biografi Imam Syafi'i (Mubarakfury, 2012, h. x-xi).

Selain itu, beliau juga mengarang sebuah kitab tentang takhrij haditshadits yang disebutkan dalam kitab At Tanbih fi Fifqhisy Syafi'iyyah. Sempat menulis karya tentang penjelasan (syarb) kitab Shabih Bukhari, tetapi belum sempat diselesaikan. Sempat menulis karya besar tentang hukum syari'at, tetapi juga tidak sempat diselesaikan (baru sampai bab haji). Kitab tentang ringkasan Al Madkhal karya Imam Al Baihaqi, tetapi sebagian besar tidak tercetak dalam bentuk kitab. Mukbtasar Ulumil Hadits: kitab ini merupakan ringkasan dari kitab Ulumil Hadits karya Abu Amar bin Shalah. Kitab ini akhirnya dicetak oleh Syekh Ahmad Muhammad Syakir, ahli hadits dari Mesir. Syekh Ahmad Muhammad Syakir juga menulis penjelasan kitab ini dan diberi judul Al Ba'its Al Hatsitsfi Syarbi Mukbtashar 'Ulumil Hadits dan setelah dicetak berkali-kali. Kitab tentang sirah Nabi Muhammad (sebagaimana juga dimasukkan dalam kitab Al Bidayah wan Nibayah) dalam dua versi: panjang dan pendek. Dan terakhir Risalah (semacam masalah) tentang jihad; diberi judul Al Ijtihad fi Thalabil Jihad dan telah dicetak berkali-kali (Mubarakfury, 2012, h. x-xi).

\section{Variasi Makna Kata Islam dalam al-Qur’an}

Beragamnya makna kata Islam dalam al-qur'an dihasilkan dari derivasi dalam kata Islam, konteks kata-kata yang berada di sebelum atau sesudah kata Islam, dan juga hasil dari bentuk-bentuk pokok kata Islam. Berikut beberapa makna kata Islam di dalam al-Qur'an:

\section{Islam (Q.S. Ali Imran: 19)}

Menurut Ibnu Katsir melalui ayat ini, Allah memberitahukan pembatasan, bahwa agama yang diterima di sisi-Nya hanyalah Islam. Dalam tafsir Ibnu Katsir Ibnu Jarir menyebutkan bahwa Ibnu 'Abbas pernah 
membaca ayat QS. Ali Imran:18. Ibnu 'Abbas membacanya dengan kasrah pada (annabu) yaitu menjadi "innahu" dan membacanya dengan fathah pada kata (inna) menjadi "anna" Artinya, Allah, Malaikat, dan orang-orang yang berilmu bersaksi bahwa agama yang diterima di sisi Allah hanya Islam. Jumhur Ulama membacanya dengan kasrah, yaitu sebagai khabar (predikat). Kedua makna tersebut benar, namun pendapat jumhur lebih tepat dan jelas (Mubarakfury, 2012, h. 32).

Sebagian mereka merasa dengki atas sebagian lainnya sehingga mereka berselisih dalam hal kebenaran lantaran mereka saling dengki dan benci serta saling membelakangi. Lalu sebagian mereka membawa kebencian kepada sebagian yang lain, kepada penentangan terhadap sebagian yang lain dalam seluruh ucapan dan perbuatannya, meskipun benar. Yaitu barang siapa mengingkari apa yang telah diturunkan Allah dalam kitab-Nya. Allah akan memberikan balasan atas perbuatan tersebut dan menghisabnya atas kedustaan yang telah diperbuatnya serta menyiksanya atas penolakannya terhadap kitab-Nya (Syaikh, n.d., h. 32).

Ayat di atas menjelaskan bahwa agama yang baik adalah agama yang di bawa oleh Nabi Muhammad dan tidak ada yang pantas disembah kecuali Allah Swt.

\section{Muslim (Q.S. Al-Hajj: 78)}

Dalam tafsir Ibnu Katsir Mujahid, 'Atha', adh-Dhahhak, as-Suddi, Muqatil bin Hayyan, dan Qatadah. Mujahid berkata: "Allah telah menamai kalian orang-orang muslim dari dahulu dalam kitab-kitab terdahulu dan di dalam adz-Dzikr. Yaitu Kami menjadikan kalian seperti itu sebagai umat yang wasath (pertengahan), adil, terpilih dan menjadi saksi bagi seluruh umat dengan keadilan kalian agar pada hari kiamat, seluruh umat mengakui kepemimpinan dan keutamaan mereka dibandingkan umat yang lain. Untuk itu, persaksian mereka diterima pada hari kiamat, yaitu tentang kenyataan 
bahwa para Rasul telah menyampaikan risalah Rabb mereka (Syaikh, n.d., h. 252).

Ayat di atas menjelaskan bahwa umat yang terbaik dan umat yang paling utama dibandingkan umat yang lain adalah umat Nabi Muhammad.

\section{Berserah diri (Q.S. An-Nahl: 81)}

Dalam tafsir Ibnu Katsir Qatadah mengatakan, pepohonan, benteng dan parit-parit. Pakaian yang terbuat dari kapas, katun, dan wol. Baju besi, tameng dan lain-lain. Maksudnya, demikian itulah Allah menciptakan sesuatu yang dapat kalian gunakan untuk berbagai kepentingan dan kebutuhan kalian supaya menjadi penolong (sarana) bagi kalian dalam mentaati Allah dan beribadah kepada-Nya (berserah diri) (Syaikh, n.d., h. 220).

Ayat di atas menjelaskan bahwa Allah menciptakan segala sesuatu untuk kepentingan dan kebutuhan bagi manusia sebagai penolong dalam mentaati dan beribadah kepada-Nya.

\section{Berserah diri (Al-Mu'min: 66)}

Ibnu Katsir menafsirkan ayat di atas bahwa Allah melarang seseorang beribadah kepada selain-Nya, berupa berhala-berhala, tandingan-tandingan dan patung-patung. Dia Tabaaraka wa Ta'ala pun telah menjelaskan, bahwa tidak ada satu pun selain-Nya yang berhak diibadahi (Syaikh, n.d., h. 283284).

Ayat di atas menjelaskan bahwa kita dilarang untuk menyembah kepada selain Allah. Karena tidak ada Ilah yang berhak disembah selain Allah Swt.

\section{Selamat (Q.S. Al-Ma'idah: 16)}

Ibnu Katsir menafsirkan ayat di atas yaitu jalan kesuksesan dan keselamatan sekaligus sebagai jalan untuk beristiqamah. Allah menyelamatkan mereka dari berbagai kebinasaan. Allah jelaskan pula kepada mereka jalan yang paling jelas dan terang. Allah palingkan mereka dari berbagai macam bahaya dan Allah antarkan mereka kepada apa yang paling mereka sukai, serta 
menyelamatkan mereka dari kesesatan, kemudian Allah bombing mereka menuju keadaan yang paling lurus (Syaikh, n.d., h. 67-68).

\section{Syari'at (Q.S. Al-Baqarah: 208)}

Ibnu Katsir menafsirkan ayat di atas yaitu Allah memerintahkan kepada hamba-hamba-Nya yang beriman kepada-Nya dan membenarkan Rasul-Nya, agar berpegang kepada seluruh tali Islam dan syari'atnya, mengerjakan perintah-Nya, serta menjauhi semua larangan-Nya sekuat tenaga.

Dalam tafsir Ibnu Katsir al-'Aufi meriwyatakan dari Ibnu 'Abbas, Mujahid, Thawus, adh-Dhahhak, Qatadah, as-Suddi, dan Ibnu Zaid: "yaitu Islam.” Dan adh-Dhahhak meriwayatkan dari Ibnu 'Abbas, Abul 'Aliyah, dan Rabi' bin Anas: "Yakni ketaatan." Qatadah juga mengatakan "Yaitu perdamaian" (Syaikh, n.d., h. 514).

\section{Perdamaian (Q.S. Al-Anfal: 61)}

Ibnu Katsir menafsirkan ayat di atas dengan Allah berfirman, bahwa jika engkau khawatir terhadap penghianatan suatu kaum, maka langgarlah perjanjian mereka itu secara timbal balik. Jika masih terus memerangi dan melanggar hakmu, maka seranglah mereka. Berdamai, memperbaiki hubungan dan penghentian peperangan. Maksudnya cenderunglah engkau kepada perdamaian tersebut dan terimalah tawaran mereka tersebut. Oleh karena itu, ketika orang-orang musyrik menawarkan perdamaian dan genjatan senjata selama Sembilan tahun antara mereka dengan Rasulullah pada saat diadakan Shulbul Hudaibiyyah (perjanjianHudaibiyyah), maka beliau pun menerima tawaran tersebut dengan mengajukan beberapa syarat kepada mereka (Syaikh, n.d., h. 91-92).

\section{Penerimaan (Q.S. An-Nisaa: 65)}

Ibnu Katsir menafsirkan Allah bersumpah dengan diri-Nya yang Mahamulia, bahwa seseorang tidak beriman hingga dia berhukum kepada Rasulullah dalam seluruh perkara. Hukum apa saja yang diputuskannya, itulah 
kebenaran yang wajib dipatuhi secara total, lahir dan bathin. Apabila mereka berhukum kepadamu, mereka mentaatimu dalam hati mereka dan tidak didapati dalam jiwa mereka rasa keberatan terhadap apa yang telah engkau putuskan, mereka pun mematuhinya secara zhahir dan bathin, serta menerimanya dengan penuh tanpa keengganan, penolakan dan pembangkangan (Syaikh, n.d., h. 438-439).

\section{Surga (Q.S. Yunus: 25)}

Ibnu Katsir menafsirkan ayat diatas yaitu ketika Allah telah menyebutkan dunia dan kecepatan hilangnya, Allah menawarkan surga dan mengajak kepadanya, Allah memberinya nama "Darussalam" (tempat tinggal yang penuh keselamatan). Maksudnya, selamat dari rintangan-rintangan, kekurangan-kekurangan dan berbagai macam musibah (Syaikh, n.d., h. 337340).

\section{Suci (Q.S. Ash-Shaffat: 84)}

Dalam tafsir Ibnu Katsir Ibnu 'Abbas mengatakan: "Yakni, kesaksian bahwasanya tidak ada ilah yang haq selain Allah." Ibnu Abi Hatim menceritakan dari 'Auf: "Aku pernah berkata kepada Muhammad bin Sirin: 'Apakah yang dimaksud dengan hati yang suci itu?' Dia menjawab: 'Yaitu hati yang mengetahui bahwa Allah adalah haq dan hari kiamat itu pasti akan datang, tidak diragukan lagi, dan bahwasanya Allah akan membangkitkan orang-orang yang berada di dalam kubur.' "Sedangkan al-Hsasan mengemukakan: "Maksudnya, selamat dari kemusyrikan" (Syaikh, n.d., h. 8182).

\section{Bersih (Q.S. Asy-Syu'ara: 89)}

Ibnu Katsir menafsirkan ayat di atas kata salim, selamat atau bersih dari kotoran dan syirik. Yang berkaitan dengan ayat yang sebelumnya yang menyebutkan bahwa semua harta dan dan anak tidak lagi berguna di hari penghabisan. Kecuali memurnikan ketundukan kepada-Nya dan membebaskan diri dari kotoran dan syirik (Syaikh, n.d., h. 511-514). 


\section{Ayat-Ayat Islam Kaffah dan Pengertiannya dalam al-Qur'an}

Pengertian Islam kaffah adalah Islam secara menyeluruh sebagaimana yang terdapat dalam QS. al-Baqarah:208

"Wahai orang-orang yang beriman! Masuklah ke dalam Islam secara keseluruban, dan janganlah kamu ikuti langkah-langkah syaitan. Sunggub ia musub yang nyata bagimu."

Dari pengertian ayat diatas berarti Islam kaffah atau Islam komprehensif adalah Islam yang mengatur seluruh kegiatan di dunia. Islam tidak hanya mengatur hubungan antara manusia dengan Tuhan (bablum minallah) yang dilaksanakan melalui ritual ibadah berupa shalat, puasa, zakat, haji, dan ibadah lainnya. Akan tetapi, Islam juga mengatur hubungan manusia dengan manusia (bablum minannas), hubungan manusia dengan dengan lingkungan sekitar (hablum minal'alam), yang dalam hal ini erat hubungannya dengan sistem sosial masyarakat, budaya, politik, hukum, teknologi, dan sebagainya (Nata, 2001, h. 5).

Adapun ayat-ayat yang membahas tentang Islam kaffah di dalam AlQur'an adalah: (a) Q.S. al-Baqarah:208, (b) Q.S. an-Nisa':125, (c) Q.S. alAn’am:153, (d) Q.S. al-An'am:162.

\section{Islam Kaffah Menurut Pandangan Ibnu Katsir}

Islam kaffah adalah Islam secara menyeluruh, yang Allah 'Azza wa jalla perintahkan dalam al-Qur'an surat al-Baqarah ayat 208. Ibnu Katsir menafsirkan ayat ini yaitu Allah memerintahkan kepada hamba-hamba-Nya yang beriman kepada-Nya dan membenarkan Rasul-Nya, agar berpegang kepada seluruh tali Islam dan syari'atnya, mengerjakan perintah-Nya, serta menjauhi semua larangan-Nya sekuat tenaga.

Mengenai firman Allah ادخلو افى السلم al-'Aufi meriwayatkan dari Ibnu 'Abbas, Mujahid, Thawus, adh-Dhahhak, Qatadah, as-Suddi, dan Ibnu Zaid: 
"Yaitu Islam." Masih dalam firman yang sama, adh-Dhahhak meriwayatkan dari Ibnu 'Abbas, Abul 'Aliyah, dan Rabi' bin Anas: "Yakni ketaatan." Qatadah juga mengatakan: "Yaitu perdamaian."

Dan firman-Nya: (kaffah) Ibnu 'Abbas, Mujahid, Abul 'Aliyah, 'Ikrimah, Rabi' bin Anas, as-Suddi, Muqatil bin Hayyan, Qatadah, dan adhDhahhak mengatakan: “(kaffah) berarti jami'an (keseluruhan).” Mujahid menuturkan: "Artinya, kerjakanlah semua amal shalih dan segala macam kabajikan.”

Di antara para mufassir ada yang menjadikan firman Allah: (kaffah) berkedudukan sebagai hall (yang menerangkan keadaan) dari orang-orang yang masuk. Maksudnya, masuklah kalian semua kedalam Islam. Dan yang benar adalah pendapat pertama, yaitu bahwa mereka seluruhnya diperintahkan untuk mengerjakan semua cabang iman dan syari'at Islam, yang jumlahnya sangat banyak, sesuai dengan kemampuan mereka (Syaikh, n.d., h. 514-515).

Islam kian terlihat dapat berperan sebagai penyelamat kehidupan manusia dari masalah dan krisis kemanusiaan multidimensional melalui sistem keagamaan (religious system) yang dipahami, dihayati dan diamalakan dalam kehidupan sehari-hari secara komprehensif, atau Kaffah (udkhulu fi alsilm al-kaffah). Pemahaman komprehensif itu selanjutnya melahirkan sikap moral dan akhlak mulia (Nata, 2001, h. vi).

Islam secara menyeluruh mengamalkan seluruh ajarannya, tanpa memilih-milih yang sesuai dengan hawa nafsu saja, meninggalkan sebagian dan mengamalkan sebagian, atau malah mengamalkan yang tidak diajarkan.

Dari uraian di atas, maka dapat dipahami bahwa Islam adalah tatanan nilai yang melingkupi segala aspek kehidupan manusia. Terutama aspek keimanan dan syari'at Islam, kedua aspek ini sangat penting dalam melaksanakan kegiatan keagamaan karena Islam tanpa keimanan dan syari'at bagaikan rumah yang tanpa tiang. Iman dan syari'at Islam adalah suatu 
pondasi yang sangat kuat dalam menjalankan Islam yang komprehensif. oleh karena itu, seseorang dalam menjalankan Islam yang komprehensif harus memiliki keimanan dan menjalankan syari'at Islam yang telah ditentukan. Semua aspek tersebut akan dijelaskan sebagai berikut:

Pertama, iman. Iman adalah landasan utama yang menjadi pondasi sebuah agama. Secara harfiah, iman berasal dari bahasa Arab, yang mengandung arti faith (kepercayaan), dan belief (keyakinan) (Nata, 2001, h. 128) dan (Wehr, 1974, h. 20). Yakin kepada Allah, keteguhan hati, keteguhan batin (Poerwadarminta, 1991, h. 375). Dalam Islam, iman atau kepercayaan yang asasi selanjutnya disebut akidah bersumberkan al-Qur'an dan merupakan segi teoritis yang dituntut pertama dan terdahulu dari segala sesuatu untuk dipercayai dengan suatu keimanan yang tidak boleh dicampuri oleh keraguan dan persangkaan (Razak, 1977, h. 119). Sementara pendapat Nashir Abdul Karim yang dikutip oleh Abu Amar dan Abu Fatiah al-Adnani, yakni keimanan yang mantab kepada Allah Swt., kepada apa-apa yang wajib bagi diri-Nya dalam ulubiyyah-Nya, keimanan kepada rasul-rasul-Nya, kepada hari akhir, kepada takdir baik dan buruk dan beriman kepada seluruh nashnash yang sahih berupa pokok-pokok agama (Amar \& Al-Adnani, 2009, h. 76).

Dari pengertian di atas dipahami bahwa iman atau akidah menjadi pondasi yang kuat dan jika ia lemah maka bangunan di atasnya pun juga tidak kokoh. Ibadah yang dilakukan akan mudah goyah apabila tidak mempunyai pondasi yang kuat. Keyakinan kepada Allah harus dipegang teguh oleh setiap umat Islam dalam menjalani setiap aspek kehidupannya di dunia. Setiap aktifitas seorang muslim harus didasari dengan akidah sehingga seluruh kegiatannya dapat bernilai ibadah di hadapan Allah Swt. Seorang muslim wajib meyakini dan mengimani semua yang datang dari Allah sehingga perbuatan yang dilakukannya bersifat baik dan akan mengantarkan ia kepada keimanan. 
Kedua, Syari'at (Islam). Kata syari'at adalah bentuk jamak dari syari'ah yang diambil dari bahasa arab yaitu syari'ah berasal dari kata syara' yang berarti jalan. Dalam perkembangannya kata syariah digunakan orang Arab untuk konotasi jalan lurus. Kata syari'ah mengandung arti jalan yang lurus dan jelas menuju kebahagiaan. Kata syari'ah juga identik diartikan ad-din (agama). Karena agama yang dapat membimbing manusia kepada kebenaran yang hakiki untuk memperoleh kebenaran (jalan yang lurus) dan kebahagiaan di dunia dan di akhirat (Mahfud, 2011, h. 22). Untuk mencapai ke jalan yang lurus dan kebahagiaan maka kita harus mengikuti ajaran dan petunjukpetunjuk dalam agama. Dalam Islam ada unsur ajaran yang harus di capai, yang paling utama adalah keimanan dan syari'at Islam.

\section{Kontribusi Penafsiran Ibnu Katsir Terhadap Islam Kaffah}

Membahas kontribusi merupakan suatu hal yang penting untuk menjelaskan apa saja argumen asli dari pengarang, yang dalam hal ini adalah Ibnu Katsir. Dalam Islam kaffah. Oleh karena itu, penulis akan memaparkan pemikiran dan penafsiran Ibnu Katsir tentang Islam kaffah tersebut. Akan tetapi, disini hanya akan menjelaskan pokok-pokok penting dalam kontribusi penafsiran Ibnu Katsir terhadap ayat-ayat yang berkaitan dengan Islam.

Menurut Ibnu Katsir Islam adalah agama. Bahwa tiada agama di sisiNya dan yang diterima-Nya dari seseorangpun kecuali agama Islam, yaitu mengikuti rasul-rasul yang diutus-Nya setiap saat hingga berakhir dengan diutusnya Muhammad saw. dengan demikian telah tertutup semua pintu menuju Allah kecuali jalan dari arah Muhammad (Syaikh, n.d., h. 31).

Pada konteks lainnya Islam mempunyai makna tunduk dan patuh kepada Alla Swt. bahwa Allah melarang seseorang beribadah kepada selainNya, berupa berhala-berhala, tandingan-tandingan dan patung-patung. Tidak ada yang berhak diibadahi selain Allah Swt (Syaikh, n.d., h. 284).

Secara lebih mengarah pada ayat-ayat al-Qur'an, beberapa hal yang penting untuk dikaji diantaranya adalah penafsiran Ibnu Katsir dalam Q.S. al- 
Baqarah: 208. Ibnu Katsir membaca as-silm yang artinya "islam" kemudian kata kaffah dalam ayat tersebut menurut Ibnu Katsir adalah sebagai hal dari assilm (menjelaskan keadaan Islam) dengan pengertian seluruh ajaran dan syari'at Islam, totalitas Islam. Ibnu Katsir berkata Allah Swt. memerintahkan para hamba yang beriman kepada-Nya dan membenarkan rasul-Nya agar mereka mengambil semuaajaran dan syari'at islam, mengerjakan semua perintah-Nya, dan meninggalkan semua larangan-Nya (Muchotob Hamzah \& Al-Munawar, 2001, h. 212-216).

Ibnu Katsir ingin menjelaskan bahwa Allah memerintahkan kepada hamba-hamba-Nya yang beriman kepada-Nya dan membenarkan rasul-Nya, agar berpegang kepada seluruh tali Islam dan syari'atnya, mengerjakan perintah-Nya, serta menjauhi semua larangn-Nya sekuat tenaga. Mereka semuanya diperintahkan untuk mengerjakan semua cabang iman dan syari'at Islam, yang jumlahnya sangat banyak seperti, shalat, puasa, zakat, dan lainlain (Syaikh, n.d., h. 514-515).

Oleh karena itu, untuk mencapai Islam yang komprehensif umat Islam harus melalui beberapa proses yang tidak mudah, yakni mencakup semua unsure relasi dalam agama meliputi hubungan dengan Tuhan, hubungan sesame manusia dan hubungan terhadap alam semesta.

Indonesia merupakan salah satu Negara yang memiliki penduduk mayoritas muslim terbesar di dunia. Indonesia merupakan Negara yang memiliki beragam kebudayaan, dengan kata lain Indonesia merupakan Negara multicultural. Adanya keragaman, dan berbagai macam budaya yang ada dalam kehidupan masyarakat yang menyangkut nilai-nilai, sistem, kebiasaan, dan politik yang mereka anut.

Hal yang harud diwaspadai adalah munculnya perpecahan etnis, budaya dan suku di dalam tubuh bangsa Indonesia. Bangsa Indonesia adalah bangsa yang kaya kebudayaan yang dibawa oleh banyak suku, adat-istiadat yang terbesar di seluruh negeri. Bukti nyata dari penerimaan Indonesia 
terhadap multikulturalisme adalah disepahamkannya pancasila sebagai landasan filosofis bangsa yang mencakup aspek-aspek kebangsaan Indonesia seperti agama, sosial, politik, dan sebagainya.

Menanggapi persoalan ini, Islam sebagai agama terbesar di Indonesia diharapkan mampu menjadi garda depan demi terwujudnya cita-cita luhur tersebut. Oleh karena itu, Ibnu Katsir dalam tafsirnya menjelaskan bahwa agama adalah kebutuhan hidup tidak ada yang dapat menggantikan agama. Semua manusia secara umum memiliki hak untuk memilih agama, agama Islam bukanlah suatu agama yang memaksa. Karena sesungguhnya dalil-dalil dan bukti-bukti itu sudah demikian jelas dan gamblang, sehingga tidak perlu ada pemaksaan terhadap seseorang untuk memeluknya. Tetapi barang siapa diberikan cahaya bagi hati nuraninya, maka ia akan memeluknya. Dan barang siapa yang dibutakan hatinya oleh Allah Ta'ala, dikunci mati pendengaran dan pandangannya, maka tidak aka nada manfaat baginya paksaan dan tekanan untuk memeluk Islam (Syaikh, n.d., h. 655).

Tidak melakukan banyak prasangka, yaitu melakukan tuduhan dan pengkhianatan terhadap keluarga dan kaum kerabat serta umat manusia secara keseluruhan yang tidak pada tempatnya, karena sebagian dari prasangka itu murni menjadi perbuatan dosa. Jangan saling memutuskan hubungan, jangan pula saling membelakangi, saling membenci dan saling dengki, janganlah kalian mencari-cari keburukan dan mengintai kesalahan orang lain, janganlah saling membenci, dan jadilah kalian hamba-hamba Allah yang saling bersaudara. Islam menganjurkan kita untuk saling menghargai, menyayangi, dan menyambung tali silaturahmi baik antar sesama manusia, budaya, agama, dan negara. Hubungan yang baik antar negara adalah dambaan Islam. Hal ini harus diawali hubungan baik dari jiwa setiap pribadi yang kemudian secara perlahan merambah ke ranah keluarga, masyarakat, sampai pada akhirnya seluruh bangsa Indonesia (Syaikh, n.d., h. 123-124). 
Dari pernyataan di atas nampak jelas bahwa pesan yang selalu disampaikan oleh Ibnu Katsir melalui penafsiran dan pemikirannya adalah syariat Islam, menjalankan semua perintah-Nya dan menjauhi semua larangan-Nya, menjaga hubungan yang baik, baik antara sesama muslimin maupun kepada masyarakat secara umum. Karena bagaimanapun agama adalah fitrah yang tidak dapat dipaksakan. Yang terpenting adalah mewujudkan hubungan yang baik antar seluruh manusia.

\section{PENUTUP}

Berdasarkan uraian dalam bab-bab sebelumnya, maka dapat ditarik kesimpulan sebagai jawaban dari rumusan masalah di atas yaitu: Pertama, Islam kaffah dalam al-Qur'an adalah Islam yang komprehensif yang mencakup seluruh aspek kehidupan, bukan hanya tentang menjalankan ibadah, tetapi juga melaksanakan syari'at Islam yang telah ditentukan dan juga menjaga hubungan antar sesama untuk bersosialisasi yang baik, terutama hubungan terhadap Allah sebagai bentuk ketaatan dan untuk mencari keselamatan di dunia dan di akhirat.

Kedua, Islam Kaffah (menyeluruh) menurut Ibnu Katsir dapat dielaborasi kepada dua unsur, pertama adalah memiliki iman sebagai pondasi yang kuat, karena suatu ibadah yang dilakukan akan mudah goyah karena tidak mempunyai pondasi yang kuat. Oleh karena itu kita harus memiliki pondasi yang kuat dengan keyakinan kepada Allah, malaikat-malaikat-Nya, Rasul-rasul-Nya, kitab-kitab-Nya dan iman kepada hari akhir. Kedua adalah syari'at Islam sebagai pondasi yang kuat dalam melaksanakan Islam yang komprehensif, karena syari'at Islam merupakan suatu aturan dan ketetapan yang Allah perintahkan kepada hamba-hambanya seperti melaksanakan shalat, puasa, zakat, ibadah haji dan lain-lain.kharus dipegang teguh oleh setiap umat Islam dalam menjalani kehidupannya di dunia. Untuk menjaga hubungan manusia terhadap Allah suatu aturan dan ketetapan yang Allah 
perintahkan kepada hamba-hambanya seperti shalat, puasa, zakat, haji, dan lain-lain.

Ketiga, Kontribusi Ibnu Katsir terhadap Islam yaitu Islam adalah agama yang terbuka dengan beragam kebudayaan. Terlebih lagi memperhatikan bahwa di Indonesia memiliki kekayaan budaya dan keberagamaan Islam. Basis multikulturalisme Indonesia menjadi landasan Ibnu Katsir dalam implementasinya keagamaan Islam yang membawa pesan bahwa Islam adalah agama yang tidak memaksa, dan membawa kedamaian bagi alam semesta.

\section{DAFTAR REFERENSI}

Amar, A., \& Al-Adnani, A. F. (2009). Mizanul Muslim; Barometer Menuju

Muslim Kaffah. Cordova Mediatama.

Izzan, A. (2007). Metodologi Ilmu Tafsir. Tafakur (Kelompok Humaniora).

Mahfud, R. (2011). Al-Islam: Pendidikan Agama Islam. Erlangga.

Mahmud, M. A. H. (2006). Metodologi Tafsir. PT. Rajagrafindo Persada.

Mohari. (2015). Konsep Islam Menurut Pandangan M. Quraish Shibab dalam Tafsir al-Misbah. UIN Sunan Kalijaga.

Mubarakfury, S. S. Al. (2008). Tafsir Ibnu Katsir I. Pustaka Imam Syafi'i.

Muchotob Hamzah, K., \& Al-Munawar, F. (2001). Tafsir Maudbu'i AlMuntaha,. Pustaka Pesantren.

Nata, A. (2001). Studi Islam Komprehensif. Kencana.

Poerwadarminta, W. J. S. (1991). Kamus Umum Bahasa Indonesia. Balai Pustaka.

Rasyid, D. (1998). Islam dalam Berbagai Dimensi. Gema Insani Press.

Razak, N. (1977). Dienul Islam. Al-Ma’arif.

Sukmadjaja, \& Yusuf, R. (2000). Indeks Al-Qur'an. Penerbit Pustaka.

Syaikh, A. bin M. A. (n.d.). Tafsir Ibnu Katsir.

Wehr, H. (1974). A Dictionary of Modern Writen Arabic. McDonald \& Evans Ltd. 